\title{
L2 Vocabulary Learning From a Lexicultural Approach: Perceptions of a Small Group of Primary Education Students
}

\author{
Gema Alcaraz Mármol \\ Universidad de Castilla-La Mancha (Ciudad Real, Spain)
}

Article received 23 July 2014, accepted 29 December 2014, final version received 26 January 2015

DOI: http://dx.doi.org/10.5565/rev/jtl3.581

\begin{abstract}
The Common European Framework of Reference (2001) states that the communicative ability in a target language is partly based on the development of attitudes, so that students are able to establish a relationship in an intercultural context. Some scholars state that language and culture are difficult to separate, as both constitute an integrated part of what is called Lexiculture. The present study shows the students' attitudes after implementing the lexicultural approach in a foreign language classroom. The aim is to find out which effect the lexicultural approach has on students' views about culture and language learning. Results show that the lexicultural approach raised motivation and widened the students' knowledge of the target words.
\end{abstract}

Keywords: attitudes, culture, foreign language learning, language teaching, vocabulary

\section{Resumen}

El Marco Común Europeo de Referencia (2001) establece que la habilidad comunicativa en una lengua meta se basa, en parte, en el desarrollo de actitudes en los estudiantes que les permitan relacionarse en un contexto intercultural. Algunos expertos hablan de la dificultad de separar lengua y cultura, puesto que ambas constituyen una parte integral de lo que se llama Lexicultura. El presente estudio trata sobre las actitudes de los estudiantes tras la implementación del enfoque lexicultural en la clase de lengua extranjera. El objetivo es encontrar qué efectos tiene dicho enfoque en cómo los estudiantes conciben el aprendizaje de lengua y cultura. Los resultados muestran que el enfoque lexicultural aumentó la motivación de estos estudiantes y amplió su conocimiento de palabras clave.

Palabras clave: actitudes, cultura, aprendizaje de lengua extranjera, enseñanza de lenguas, vocabulario

\begin{abstract}
Resumée
Le Cadre Européen Commun de Référence pour les Langues (2001) établit que la capacité communicative en une langue cible est basée partiellement sur le développement d'attitudes des étudiants leur permettant de s'exprimer dans un contexte interculturel. Il y a des experts qui affirment que langue et culture sont difficiles à séparer car les deux font partie de ce qui est appelé Lexiculture. Cette étude analyse les attitudes des étudiants suite à une mise en place de l'approche lexiculturelle dans une classe de langue étrangère. Le but de ce travail est de trouver les effets de cette approche sur la conception que les étudiants ont de l'apprentissage de langue et culture. Les résultats montrent que l'approche lexiculturelle a augmenté la motivation des étudiants ainsi que la connaissance de mots clés.
\end{abstract}

Mots clés: attitudes, apprentissage de langue étrangère, enseignement de langues, culture, vocabulaire 


\section{Introduction}

Nowadays, the world seems to be multicultural and multilingual. The phenomenon of immigration, international tourism and globalization all point towards multilingualism. Blommaert and Backus (2012) use the term "superdiversity" to denote the "new dimensions of social, cultural and linguistic diversity emerging out of post-Cold War migration and mobility patterns" (Vertovec in Blommaert \& Backus, 2012, p. 13). Indeed, the ability to use -if only at a basic level- more than one language is becoming the rule and not the exception. What is more, groups and identities are becoming blurred and it is more and more difficult to associate people with a particular category. Due to the current situation "the empirical field has become extremely complex, and descriptive adequacy has become a challenge for the social sciences as we know them" (Blommaert \& Backus, 2012, p. 13). The present situation has raised governmental awareness of the need for the introduction of a compulsory second language from the first educational stages.

Highlighting the importance of vocabulary in L2 acquisition has become a cliché given the bulk of literature currently available about this issue. Vocabulary has always been present in the history of language teaching, although the attention received has waxed and waned along the years. The approach to vocabulary has been going through many changes depending on the teaching method adopted. For instance, with the traditional Grammar Translation method vocabulary was introduced by means of lists which students had to study by heart. Alternatively, in the Audiolingual method vocabulary was conceived as merely illustrative for linguistic structures (Sánchez, 2009). It was towards the mid-seventies when vocabulary definitely stood out as one of the cornerstones -some would say the cornerstoneof L2 teaching. In fact, not only has that interest been maintained during the eighties and nineties, but it has considerably increased in the last two decades.

The Common European Framework of Reference for the Teaching, Learning and Evaluation of Languages (2001), hereafter CEFR, states that foreign languages must be understood as "partícipes en la construcción de un conjunto de conocimientos y capacidades de los alumnos, así como en un proyecto de socialización válido para un modelo de sociedad que exige a los individuos que la conforman aptitudes para las relaciones interculturales [taking part in constructing knowledge and developing certain abilities, so that students can be part of a social model which requires intercultural aptitude]" (Vez, 2002, p. 20). As we can infer from those words, L2 learning should not be merely considered a linguistic question, but also a sociocultural issue, where the cultural knowledge of the L2 community stands as one of 
the goals for the learners. Despite this declaration of intent, it seems that teaching and learning culture in the L2 classroom remains exactly that way: a declaration of intent. The reason might be twofold: on the one hand, teachers and authorities cannot find the specific place culture should have in language learning; on the other hand, even if that place were found, there would be a hot debate as to how to get culture to occupy that place (Lafayette, 1988; Kramsch, 1995; Robinson-Stuart, 1996; Thanasoulas, 2001; Atay, 2005).

In the current study a group of primary education students was taught English as a Foreign Language under the lexicultural approach. Their attitudes towards language learning and culture were analysed after a lexicultural session by means of an ad hoc questionnaire. The results obtained from this group were compared to those obtained from a control group which did not experience the lexicultural approach.

\section{The cultural dimension of vocabulary learning: The lexicultural approach}

The scarce importance attributed to the cultural dimension is reflected in the concept of language learning and more specifically vocabulary learning. Having a look at different word knowledge proposals, we can argue that L2 learning has been considered primarily and almost exclusively a linguistic issue. Allusions to the cultural dimension are almost inexistent or highly unspecific. Richards (1976) was one of the first authors to highlight the need for the definition of word knowledge. He built up a list of seven aspects that would constitute this concept. Each of those aspects corresponds to one type of sub-knowledge that students should learn in order to know a word:

- knowing the degree of probability of encountering the word in speech or print;

- knowing the limitations imposed on the use of the word according to function and situation;

- knowing the syntactic behaviour associated with the word;

- knowing the underlying form of a word and the derivations that can be made of it;

- knowing the associations between the word and other words in the language;

- knowing the semantic value of the word;

- knowing many of the different meanings associated with the word.

Almost twenty years later, Nation (2001) introduced another taxonomy. That time the list was made up of nine different aspects that gathered around three dimensions: form, meaning and use. The first dimension refers to the spoken and written form, as well as word parts (affixes). As for the meaning dimension, Nation highlights the meaning-form link of the word, the concepts and referents conveyed by that meaning, and word associations. Finally, word use is comprised with grammatical functions, collocations and register constraints. 
Despite differences in time between the two proposals, ideas on word knowledge don't seem to have changed much. Both authors mainly focus on the linguistic aspects of the word, but at the same time they seem to touch upon some cultural aspects such as the use of the word according to function and situation in the case of Richards (1976), or the allusion to concepts and referents in the case of Nation (2001).

However, we are still far from including the cultural dimension as an integral part of language teaching materials (Thanasoulas, 2001). Materials do not normally offer any systematization of the cultural component of the target language. Their cultural allusions are generally scarce and frequently go unnoticed (Atay, 2005). As for teachers, even though many of them are willing to treat the target language culture in their classrooms, they normally lack training. What is more, given the busy planning of an academic year, culture ends up being the great scapegoat of the foreign language syllabus (Bennet, 1997). Allen (1985) comments on the situation of foreign language culture by stating that "despite the talk of communication and culture, and the desire for their attainment, energies are devoted instead to grammar and vocabulary [...] Culture, by contrast, is diffuse; difficult to grasp, translate into instructional goals, test, evaluate, and order" (Allen, 1985, p. 145).

As seen above, Allen points out one of the main weaknesses of the cultural dimension in relation to the foreign language classroom: its definition. Byram and Morgan (1994, pp. 5152) defines culture in terms of:

- social identity and social groups: they illustrate the complexity of national society and social identity;

- social interaction: conventions of verbal and non-verbal behaviour;

- belief and behaviour: moral and religious beliefs, routines and behaviours as social group and from daily life;

- socio-political institution: those in charge of health-care, law, social security, government;

- socialization and life-cycle: family, school, employment and the ceremonies related them;

- national history: periods and events important for the constitution of the nation;

- national geography geographical factors which are essential information for the outsiders;

- national cultural heritage: cultural artefacts which are considered emblems of national culture for past and present;

- stereotypes and national identity: notions of what is typically from that country, its origins and meanings.

Byram and Morgan's idea is not far from that found in other authors such as Vez (2002), although the latter gathers up all those cultural elements into three categories. The first category is called 'universal', and it involves theoretical requirement linked to 
intellectual tradition, arts and literature. Examples of universal culture are The Quixote by Cervantes, or The Giocconda by Leonardo. The second type of culture is materialized into monuments, historical facts and stereotypes such as The Big Ben, The Assault of the Bastille or the wet weather in the UK. Finally, there is a third type of culture called 'the local culture' which corresponds to a set of everyday functions and practical notions in which a language is involved. Therefore, to Byram and Morgan as well as to Vez (2002), culture encompasses several things from literature and arts to stereotypes and national identity, passing through history or geography.

However, Brooks (1997) argues that culture is not geography, history, folklore, sociology or civilization: "the concept [of culture] must be developed according to the needs and insights of those immediately concerned" (1997, p. 11). At present, foreign language learning at school is not considered just an academic subject, but a tool for communicating with speakers of that foreign language. Thus, in the context of foreign language teaching, a definition of culture should cater for the learners' needs, which are primarily communicative and functional. In order to achieve what we can call 'full communication' not only linguistic signs are necessary. Culture is also essential. The aim of the intercultural dimension in language teaching consists of turning learners into intercultural speakers or mediators (Byram, Gribkova, \& Starkey, 2002). This type of learner is expected to be able to engage with complexity and multiple identities. In this line, the intercultural framework can help learners become linguistically competent, at the same time they can learn to interact with people as complex human beings.

Therefore, we shall adopt Brooks' definition of culture, which nicely dovetails within the context of foreign language classroom: "culture is the fact of some words to have a number of meanings that are not only sharply different but at times contradictory" (Brooks, 1997, p. 22). Different from proposals above, Brooks' definition directly relates culture and words as parts of the same thing going hand in hand in the learning process.

Nevertheless, despite the difficulties and weaknesses regarding the presence of culture in foreign language classrooms, the need for understanding culture is appreciated by teachers and institutions. However, culture is generally seen as a mere support to linguistic proficiency rather than one of the integrated parts of the course (McLaughling, 1987). Teaching methods nowadays point to a functional communicative use of the language, as students should be able to cope with different professional and social situations. Therefore, language should be presumably taught in a meaningful and sociocultural context, and it seems that culture is 
paramount to fulfil this aim. As Byram and Morgan hold, "a thorough understanding of the language can only be gained by understanding the cultural context which has produced it" (Byram \& Morgan, 1994, p. 11).

Given the close link between language and culture many linguists claim for the need of integration of culture into the foreign language classroom (Galisson 1988, Lafayette, 1997, Pesola, 1991). In this sense, Gallisson (1988) commented on the existent relationship between language and culture by remarking the three important roles of the former with respect to the latter:

- Language is a vehicle for culture. It is by means of language that science, arts and literature expand.

- Language is a cultural product. Language is adapted to cultural changes in society. For instance, with the advent of computers and the Internet many new words have arisen and some others have adopted new senses. This is the case of the Spanish verb 'navegar' (sail). Originally, 'navegar' consisted of going in a vehicle across the water. Nowadays, 'navegar' is also used with the meaning of 'browsing'.

- Language produces culture. It is by means of the communication between individuals in a group that collective attitudes are established.

In the same line, Pesola (1991) points out that "whatever goals may be chosen for culture [...] its role will be most effective if it becomes a key component of an integrated learning environment" (p. 337). In the same vein, Byram and Morgan (1994) also remark that "it is axiomatic [...] that cultural learning has to take place as an integral part of language learning" (p. 5). We should highlight the terms integrated and integral are not chosen arbitrarily. They could not be substituted for others such as complementation or addition. That is to say, something which complements or adds to another thing does not necessarily hold the same status as the former. The complement normally has a secondary status. In fact, it mirrors the situation of the cultural dimension in the current learning scope where, at best, culture has a secondary role in the foreign language classroom. In turn, the word integration encompasses a complete turnabout in the way culture should be conceived in foreign language learning. If culture is integrated into the classroom, it becomes part of the lesson at the same level as language may be. Thus, instead of introducing some cultural aspects in a language lesson, we should present a language-and-culture lesson.

This is the idea behind Galisson's proposal (1988) of the term 'lexiculture'. For Galisson the term lexiculture should be considered a concept that manifests the complex relationship between language and culture. The origin of this term can be found in Galisson's concept of teaching and learning a foreign language. He refers to the language-culture discipline as only one and inseparable discipline, constituting a single entity. He considered 
lexiculture as an adequate concept which helps to organize phenomena which go hand in hand in an effective way (Stengers, 1987).

Guillén (2003) suggests a series of advantages for students if the lexicultural approach is adopted. In the first place, regarding conceptual accuracy, one of the problems that foreign language students have to confront is their lack of knowledge about the conceptual world that the foreign language represents. Put another way, when we try to learn a new foreign word we tend to transfer the conceptual image of that word from our L1. Not unusually, the concept behind the L1 and the L2 equivalents is not exactly the same in both languages. For instance, the word 'lunch' in English refers to that part of the day between 12.00 and 14.00 when people have a small amount of food, usually a sandwich or a piece of cake. However, if we ask a native speaker of Spanish to define the word almuerzo, the idea will surely be different from that of a native speaker of English. Hence, the Spanish idea of almuerzo would point to a part of the day between 14.00 and 16.00 when people have their main meal. As we can see, the Spanish and English ideas of 'lunch' or 'almuerzo' are considerably different. If teachers want a Spanish learner of English to have an accurate concept of what the word 'lunch' really means for English speakers, they should not confine themselves to translating that word, but to integrating it in the English cultural environment.

The second advantage mentioned by Guillén (2003) is the authentic learning context which derives from the language-culture integration. Teaching a foreign language within the cultural context where that foreign language develops contributes to a better and more comprehensive learning process. Thus, vocabulary presented in contextual-related categories appears to be more appropriate than other criteria for presentation such as the alphabetical order or the grammatical status. Grouping words that are linked to specific situations such as shopping, schooling or health care helps students to be communicatively competent. In this way, they will learn which terms and linguistic formulae are typically found in different acts of speech -which will lead them to a more authentic and complete learning of the language.

The last, but by no means the least, important advantage for students is motivation. Motivation has a primary role in all stages of language learning and at all ages. However, it is especially relevant at beginner levels and even paramount when beginners are young learners. As a general rule, when adults start learning an L2 they are intrinsically or extrinsically motivated. That is, they study a new language either because they like it or because they need it. However, in the case of children the situation is different. The foreign language stands as a compulsory subject in the curriculum. Children do not normally see the point in learning to 
speak and write a language other than their own, and they often find the task tedious (Halverson \& Halverson, 2011, p. 206). That is why it is important to develop foreign language lessons within a cultural environment, so that children's curiosity may arise. Accordingly, they are expected to be more motivated and eager to learn more about those people who speak differently, and consequently, more about that new language.

\section{Aim of the Study}

The aim of the study is to explore the students' perceptions towards language learning and culture after an EFL session adopting a lexicultural approach. In order to do so, the following research questions are displayed:

- Did the students' cultural awareness increase?

- Did the students' motivation towards language learning increase?

\section{Methodology}

\section{Participants}

Forty eleven-year-old students of English as a Foreign Language took part in the study. Their level of English was elementary and they were in their fifth year of Primary Education. They all belonged to the same state school located in Molina de Segura, an urban area of the Region of Murcia, South-East of Spain. Students had a Spanish or Latino origin, but all of them were born in Spain. They only spoke Spanish and studied English as a Foreign Language. None of them had extra lessons or studied any other language. Students were divided in two groups which were taught by the same English teacher. The teacher had a wide teaching experience. The fact that the same teacher controlled both groups was neutralized because she did not know the aim of the study. She was just asked to work some English content with the children by using different types of activities in each group.

Twenty students were included in an experimental group and the other twenty students were included in the control group. The students' level of English was similar. The experimental group worked with a didactic sequence framed within the lexicultural approach, whereas the control group followed the usual activities established in the English coursebook they usually worked with. The coursebook followed a communicative approach. The experimental group did not follow the book in this study. 


\section{Task design}

Both groups work the same content but the experimental group followed a teaching sequence with four different activities each. The didactic sequences took around 45 minutes. Activities had similar duration from 10 to 15 minutes each. The experimental group did lexicultural activities, whereas the control did the activities that were contained in the coursebook that they usually followed.

The goal of these activities was to learn different types of food and meals, together with the parts of the day. Four ad hoc activities were designed based on the lexicultural principles, that is, promoting reflection about cultural aspects, in this case eating habits. The sequence showed situations which were culturally different in Spain and in the UK as regards eating habits and types of food. At the same time, new vocabulary in the target language was introduced and dealt with by the students. In the first task students were asked to answer different questions related to eating habits, and discuss their answers with their partners. Some of these questions were "what do you usually eat for breakfast? Do you think people in other countries such as the UK have the same as you for breakfast? What time do you normally have dinner?". The second part of the activity consisted of naming different types of food that appeared in several pictures. The pictures showed people in Spain and England eating diverse types of food at different hours. We then asked children to translate them. We intentionally showed some words which had no accurate translation such as "pudding" or "churros". Others such as "ham" or "bread" aimed to be controversial as the picture under that word did not correspond to what it is normally identified as "jamón" or "pan" in Spain (Figure 1). To finish this second part of the sequence, students had to complete a chart with the different parts of the day and the different types of food from the previous pictures that they normally eat during the day and that people in England usually eat (Figure 2). In the third part of the sequence students discussed with their partners about the similarities and differences between eating habits in Spain and the UK, comparing the chart that they have completed beforehand and the pictures previously shown by the teacher. Finally, the last activity consisted of students being asked to think and comment in pairs about other differences in eating habits between Spain and the UK, as well as other situations where differences in habits can be identified. 


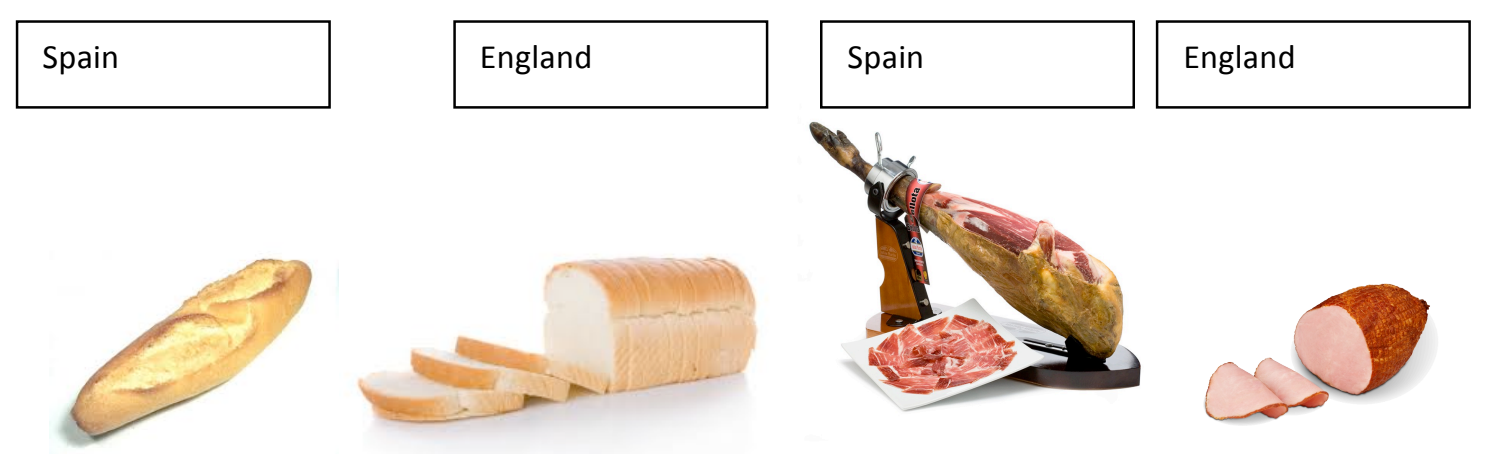

Figure 1. Food represented in different countries

Some features of the sequence might not be considered lexicultural in isolation, but the sequence itself promotes reflection about cultural aspects at the same time foreign language is learned. With this sequence culture and language are interwoven; students are learning language through culture and culture through language.

\begin{tabular}{|l|l|l|l|l|}
\hline & Breakfast & Lunch & Dinner & Supper \\
\hline English people & & & & \\
\hline Spanish people & & & & \\
\hline
\end{tabular}

Figure 2. Chart to complete with different food names

The sequence implemented in the control group also consisted of four activities. These activities were extracted from the coursebook that students regularly followed. No comparison between English and Spanish types of food or eating habits in one culture or another was done. In this case the activities were merely based on linguistic aspects. In the first place, students had to match a list of food names with their corresponding pictures. The type of food that was shown did not imply any cultural conflict, for instance "apple", "water" or "chicken", which are usually represented and conceived in a similar way by different cultures. In the second activity students were asked to complete food names with the correct missing letters. The third part of the activity consisted of students making a list of favorite food in pairs. Finally, they were asked to tell a partner about the kind of food they usually have for breakfast, lunch and dinner and discuss who had a healthier diet. In this type of activities no allusion to the cultural context is done. Vocabulary and communicative skills are treated, but no cultural allusion is done. 


\section{Data compilation}

After the students had carried out the corresponding activity, both groups were asked to answer a survey in order to know their impressions about the activity they had done. The survey was designed upon a Likert-type scale (Likert, 1974). It is the most widely used approach to scaling responses in survey research. When responding to a Likert questionnaire item, respondents specify their level of agreement or disagreement on a symmetric agreedisagree scale for a series of statements. Thus, the range captures the intensity of their feelings for a given item. The Likert-type scale normally includes five levels for each item: 'Completely agree', 'agree', 'partly agree', 'disagree', 'completely disagree'.

The scale used in this study included eight items which aim at shedding light to the two research questions above. Given the level of the participants, the survey was written in Spanish so that we could make sure that they perfectly understood what they were asked:

1) He aprendido nuevo vocabulario con estas actividades [I have learned vocabulary with these activities]

2) Gracias a estas actividades, he comprendido que aprender vocabulario va más allá de aprender la forma y el significado [Thanks to these activities, I have understood that learning vocabulary involves more than learning form and meaning]

3) Gracias a estas actividades, me he dado cuenta de que hay diferencias culturales entre hablantes de diferentes lenguas [Thanks to these activities, I have realized that there are cultural differences between speakers of different languages]

4) Este tipo de actividades me ayuda a aprender vocabulario de una manera mejor que otras [This type of activities helps me learn vocabulary in a better way than others]

5) Este tipo de actividades ha aumentado mi interés en una cultura distinta a la mía [This type of activities raises my interest in a different culture]

6) Este tipo de actividades me motiva de manera que siento que quiero estudiar vocabulario en inglés [This type of activities motivates me, so that I want to study the vocabulary of this target language]

7) Este tipo de actividades me hacen darme cuenta de que hay palabras que no tienen un equivalente exacto en mi lengua o vice versa [This type of activities makes me realize that there are words in the target language that has no equivalent in my L1 or viceversa]

8) Estas actividades me animan a estudiar inglés [These activities encourages me to study English] 
Items 1 and 4 are related to the meaning-form reinforcement. Items 2, 3, 5 and 7 refer to the enrichment of the meaning-form link, that is to say, going beyond this link and focusing on other aspects of the word such as the cultural ones. Finally, items 6 and 8 focus on the motivational effects of the activity on the students.

The procedure is the same in both groups. The teacher introduced and explained the activity to each group. The session took 45 minutes. While students were working in pairs, the teacher was walking around the tables and helping students. After the activity was carried out students were asked to complete a survey about the session.

\section{Data analysis}

We summarized the central tendency of responses from a Likert scale by using the media. Non-parametric tests should be preferred for statistical inferences. It is considered that a parametric analysis is justified for a Likert scale in some cases, but this is only possible when the Likert scale has suitable symmetry and equidistance, so an interval-level measurement can be approximated and reasonably inferred. However, the levels established in the Likert scale used in this study are not equidistant and, consequently, a parametric analysis cannot be used. That is why in this case we used the Mann-Whitney test (Dyer, 1995). It is a non parametric analysis which allows us to find out whether one of two samples tends to have larger values than the other. In this case, it was used to know whether the experimental group- that which worked with a lexicultural activity- obtained larger values in the Likert scale than the control group. We used the Mann-Whitney test in order to know whether the different scores between the experimental and the control group were statistically significant. Results show that there are strong significant differences in most items.

\section{Results}

Two research questions were displayed at the beginning of this study in order to explore the effect of the lexicultural approach on vocabulary in foreign language learning. The first question referred to knowing a word beyond the meaning-form link. The second one was related to the students' motivation in the study of vocabulary.

Did the students' cultural awareness increase? 
Table 1 (below) shows the media for the two groups as regards the eight items that constituted our survey. As for the experimental group- that is those students under the lexicultural approach - results for all items except for one are over 3. Items 3, 5, 6 and 8 show the highest scores. Items 3 and 5 deserve special attention. They refer to the learners' cultural awareness. It may be obvious to argue that the lexicultural activity promotes cultural learning. Yet, it should not be taken for granted that the learner is necessarily aware of that type of learning. This is what it is shown by the high scores of items 3 and 5 in the experimental group, item 3 obtaining the highest score with 4.60 out of 5 .

As for the control group, all the items related to cultural awareness (items 2, 3, 5 and 7) show scores below 2 over 5. For instance, items 2 and 5 present the same score (1.50). Students in the control group seem to consider that learning a word implies only knowing the link between meaning and form and they seem to show indifference towards cultural aspects. These findings lead us to think that the control group does not have a comprehensive view of the foreign language vocabulary they are exposed to. Their view about what learning vocabulary consists of and their lack of interest in culture might imply a narrow view of vocabulary learning in particular and, possibly, of language learning in general. In question 3 - thanks to this activity, I have realized that there are cultural differences between speakers of different languages - the mean score is slightly higher (1.65), but still below 2 .

\section{Did the students' motivation towards language learning increase?}

Item 4 shows the lowest mark in the scale with 2.65 over 5. This item compared the lexicultural activity to other ways of learning vocabulary. A possible reason for the low score could be attributed to the lack of specificity about 'other ways' in the statement. Maybe students did not understand which 'other ways' they could compare the activity they had just done, so that the item was not specific enough. Items 6 and 8 focus on motivation. Both items present marked high scores showing that the lexicultural activity was seen by students as highly motivating.

Results in the control group showed lower scores than the experimental group. All items except for item 1 presented scores under 2. The lowest scores corresponded to 6, 7 and 8. Students in the control group did not find their activities motivating. However, we find an exception among these negative results. Scores in item 1 are reasonably closed to the experimental group with 3.30 in the former and 3.80 in the latter. 
Table 1. Scores for the experimental and control group

ITEM

1. I have learned vocabulary with this activity
EXPERIMENTAL GROUP 3.80 3.70 2. Thanks to this activity, I have understood that learning vocabulary involves more than learning form and meaning

\begin{tabular}{|c|c|c|c|}
\hline $\begin{array}{l}\text { 3. Thanks to this activity, I have } \\
\text { realized that there are cultural } \\
\text { differences between speakers of } \\
\text { different languages }\end{array}$ & 4.60 & 1.65 & .000 \\
\hline $\begin{array}{l}\text { 4. This type of activity helps me learn } \\
\text { vocabulary in a better way than others }\end{array}$ & 2.65 & 1.75 & .000 \\
\hline $\begin{array}{l}\text { 5. This type of activity raises my } \\
\text { interest in a different culture }\end{array}$ & 3.95 & 1.50 & .000 \\
\hline $\begin{array}{l}\text { 6. This type of activity motivates me, so } \\
\text { that I want to study the vocabulary of } \\
\text { this target language }\end{array}$ & 3.95 & 1.40 & .000 \\
\hline $\begin{array}{l}\text { 7. This type of activity makes me } \\
\text { realize that there are words in the target } \\
\text { language that has no equivalent in my } \\
\text { L1 or vice versa }\end{array}$ & 3.50 & 1.25 & .000 \\
\hline $\begin{array}{l}\text { 8. This type of activity encourages me } \\
\text { to study vocabulary }\end{array}$ & 3.95 & 1.40 & .000 \\
\hline
\end{tabular}

\section{Discussion}

The experimental group- which was within the lexicultural approach - showed higher marks in their opinions about the activities that they had done. Those students who worked with a lexicultural activity claimed to have a more comprehensive knowledge - including cultural knowledge - about the words they worked with. This is one of the proposals found in the Common European Framework of Reference (2001). According to this principal document, not only should students have linguistic knowledge, but they must also go beyond the strictly linguistic, as correct communication in the target language involves the ability to use the appropriate words in specific contexts and situations, thus linking use to culture. In fact, scholars such as Richards (1976) and Nation (1990) state in their taxonomies that having a really comprehensive knowledge of a word involves going beyond meaning and form. Richards (1976) talks about knowing the limitations imposed on the use of the word according to function and situation. The cultural aspect of the word is also found in Nation's 
taxonomy within the section of 'concepts and referents'. Indeed, the same concepts and referents from one language to another may carry different associations in those languages. Therefore, the items which can correspond to one concept or have one referent in one language can have others in another language.

It is also important to highlight that the experimental group considered the lexicultural activities highly motivating in comparison to the non-lexicultural activities carried out by the control group. The two items referring to that issue practically reach 4 points out of five, as opposed to the scores of the second group which are far below 2. This aspect should be highlighted because the motivating effect of an activity can be essential at all ages, but especially when it comes to young learners. The motivating character of a set of activities does not only have a short-term effect but also a mid-term and even a long-term effect. That is to say, the approach of a specific activity can lead students to be interested in doing that activity, so that they can become encouraged to keep on learning about the subject which that set of activities deals with, going beyond those activities themselves.

Indeed, integration of language and culture should not be considered as something anecdotal that appears from time to time in a specific task. In fact, it should be part and parcel of the teaching and learning of a foreign language. In this respect it is important to highlight that a basis must be established for this integration to be possible. Accordingly, an effort from all members of the teaching community is recommended, departing from the coordination between materials designers, teacher trainers, foreign language teachers and researchers.

Material designers might consider the possibility to present culture and language as fully and naturally interwoven. This might help teachers and learners receive the message that culture is not a complement, but an integral part of language learning. We are aware though that integration between language and culture may not be easy, so further research should be done in order to explore a valid formulae for that.

In this line, teachers could be encouraged and trained in the adoption and implementation of a lexicultural approach. One of the issues that could be treated, among others, is the selection and adaptation of didactic materials towards a lexicultural framework. Finally, we should not forget the role of researchers and their contributions to the field. The research community should promote studies with a direct application to the classroom. This type of studies can help to detect learning deficiencies, which is usually a first step towards their solution. 


\section{Limitations of the study and future research directions}

The present study has yielded preliminary findings about the implementation of a lexicultural approach in the formal context of EFL, but its design is not without flaws and a number of caveats need to be noted. The first limitation concerns the number of students involved, so firm conclusions about the effect of a lexicultural approach on cultural awareness and motivation cannot be drawn. It is important to bear in mind that investigating with underage students requires a series of legal permits that are not easy to obtain. This study was suggested to different schools, however many of them were reluctant to participate, including the heads of the schools as well as the teachers and some parents. That is why the study was carried out in just one school. Nonetheless, future research contemplates more schools and bigger groups of participants.

Another limitation of the current study is that our results are based on one single session. Admittedly, solid conclusions based on one didactic sequence cannot be drawn. We expect to implement the lexicultural approach during several weeks or even a whole school term in future studies, as well as a extending the study to include a greater variety of activities, which can further support our results.

A final point to indicate is that the questionnaire used in the study consisted of eight items dealing with cultural awareness and motivation for the study of the target language. Some of the questions may seem to be too leading, but given the age of the participants (10 to 11 years old), full understanding of those items was a priority for the researchers and this weighed more in the survey design than whether the questions would orient the participants towards a particular response. For this reason, a pilot study to validate a new questionnaire with more accurately designed items will be carried out.

\section{Final Remarks}

Those students who worked with a lexicultural activities felt they had acquired a more comprehensive knowledge about the target words. In addition, they indicated that the lexicultural way of approaching vocabulary was motivating for them. The results yielded by the study suggest the positive effect of integrating language and culture in the foreign language classroom. It can also contribute to designing teaching materials and interventions that promote a comprehensive development of the ability to communicate in a target language that goes beyond what is strictly linguistic-based knowledge of the target language. 


\section{References}

Allen, W. (1985). Towards cultural proficiency. In A. Omaggio (Ed.) Proficiency, curriculum, articulation: The ties that bind (pp. 137-166). Middlebury, Vermont: Northeast Conference.

Atay, D. (2005). Reflections on the cultural dimension of language teaching. Language and Intercultural Communication, 5(3), 222-236. http://dx.doi.org/10.1080/14708470508668897

Bennet, M. (1997). How not to be a fluent fool: understanding the cultural dimension of language. In A. Fantini (Ed.) New ways in teaching culture (pp. 16-21). Alexandria: TESOL Series.

Blommaert, J., \& Backus, A. (2012). Superdiverse repertoires and the individual. In I. De Saint-Jacques \& J. Weber (Eds.) Multimodality and multilingualism: Current challenges for educational studies (pp. 11-32). Rotterdam: Sense Publishers.

Brooks, N. (1997). Teaching culture in the Foreign Language classroom. In P. Heusinkveld (Ed.), Pathways to culture (pp. 123-128). Yarmauth, Maine: Intercultural Publications.

Byram, M., \& C. Morgan (1994). Teaching and learning language and culture. Clevedon, Avon: Multilingual Matters.

Byram, M., Gribkova, B., \& Starkey, H. (2002). Developing the intercultural dimension in language teaching: a practical introduction for teachers. Strasbourg: Council of Europe.

Common European Framework of Reference for Languages 2001. Accessed April 27, 2012 from $<$ http://www.coe.int/t/dg4/linguistic/Source/Framework_EN.pdf $>$.

Dyer, C. (1995). Beginning research in psychology: A practical guide to research methods and statistics. Oxford: Blackwell Publishers.

Galisson, R. (1988). Culture et lexiculture partagées: les mots comme lieux d'observation des faits culturels. Études de Linguistique Appliquée, 69 (1), 74-90.

Kramsch, C.J. (1995). The cultural component of language teaching. Language, culture and curriculum 8 (2), 83-92. http://dx.doi.org/10.1080/07908319509525192

Guillén, C. (2003). Une exploration du concept «lexiculture» au sein de la Didactique des Langues-Cultures. Didáctica (Lengua y Literatura) 15 (2), 105-119.

Halverson, R., \& Halverson, E. (2011). Education as design for learning: A model for integrating education inquiry across research traditions. In C. F. Conrad \& R. C. Serlin (Eds.) Sage handbook for research in education: Engaging ideas and enriching inquiry (pp. 25-38). Thousand Oaks, CA: Sage.

Lafayette, R. (1988). Integrating the teaching of culture into the foreign language classroom. In A. J. Singerman (Ed.) Towards a new integration of language and culture (pp. 4762). Northeast Conference on the Teaching of Foreign Language. Middlebury, VT: Northeast Conference.

Lafayette, R. (1997). Teaching culture: Strategies and techniques. Washington: Center for Applied Linguistics.

Likert, R. (1974). The method of constructing an attitude scale. In G. Maranell (Ed.) Scaling: A sourcebook for behavioural scientists (pp.232-243). New Jersey: Transaction Publishers.

McLaughling, B. (1987). Theories of second language learning. London: Arnold.

Nation, P. (1990). Teaching and learning vocabulary. Boston: Heinle and Heinle. 
Nation, P. (2001). Learning vocabulary in another language. Cambridge: Cambridge University Press.

Pesola, C. (1991). Culture in the elementary school foreign language classroom. Foreign Language Annals, $24 \quad$ (3), 331-346. http://dx.doi.org/10.1111/j.19449720.1991.tb00478.x

Robinson-Stuart, G. (1996). Second culture acquisition: Ethnography in the foreign language classroom. The Modern Language Journal, 80 (4), 431-449. http://dx.doi.org/10.1111/j.1540-4781.1996.tb05463.x

Richards, J. (1976). The role of vocabulary teaching. TESOL Quarterly, 10 (1), 77-89. http://dx.doi.org/10.2307/3585941

Sánchez, A. (2009). La enseñanza de idiomas en los últimos cien años. Métodos y enfoques, Madrid: SGEL.

Stengers, I. (1987). D’une science à l'autre: Des concepts nómades. Paris: Seuil.

Thanasoulas, D. (2001). The importance of teaching culture in the Foreign Language classroom. Radical Pedagogy. Accessed June 2014

https://media.startalk.umd.edu/workshops/2009/SeattlePS/sites/default/files/files/The

\%20Importance $\% 20$ Of $\% 20$ Teaching $\% 20$ Culture $\% 20$ In $\% 20$ The $\% 20$ Foreign $\% 20$ Lang uage $\% 20$ Classroom.pdf

Vez, J.M. (2002). The teaching of English as a foreign language: A European perspective. Sevilla: Universidad de Sevilla.

\section{Acknowledgements}

The author would like to thank the reviewers for their comments, which have been really helpful to improve the quality of this paper.

\section{Author's Biodata}

Gema Alcaraz-Mármol is an assistant professor in the Department of Modern Languages (UCLM). She currently teaches CLIL Methodology and EFL Methodology in the Primary Education degree. Her lines of research include language teaching, corpus linguistics and L2 vocabulary acquisition.

Email: gema.alcaraz@uclm.es

To cite this article:

Alcaraz Mármol, G. (2015). L2 vocabulary learning from a lexicultural approach: Perceptions of a small group of primary education students. Bellaterra Journal of Teaching \& Learning Language \& Literature, 8(1), 28-45. http://dx.doi.org/10.5565/rev/jtl3.581 